\title{
PHOTOTHERAPY IN COMPLEX TREATMENT OF WOUNDS IN PATIENTS WITH ISCHEMIC AND NEUROISCHEMIC FORM OF DIABETIC SYNDROME
}

\author{
Yu.V. Ivanova \\ Dr.Sci. (Med.), Principal Researcher \\ Department of Surgical Infections \\ SI "Zaycev V.T. Institute of General and Urgent Surgery \\ of NAMS of Ukraine" \\ 1 Balakirjeva entrance, Kharkiv, 61103, Ukraine \\ tel.: +38 (057) 349-41-94 \\ e-mail:dr.mushenko@gmail.com \\ ORCID 0000-0001-8773-6827
}

\section{V.A. Prasol}

Dr. Sci. (Med.), Head of the department

Department of Acute Vascular Diseases

SI "Zaycev V.T. Institute of General and Urgent Surgery of NAMS of Ukraine"

1 Balakirjeva entrance, Kharkiv, 61103, Ukraine

tel.: +38 (057) 349-41-71

e-mail:dr.mushenko@gmail.com

ORCID 0000-0002-0556-6981

\section{A.M. Korobov}

Cand. Sci. (Phys.-Math.), Head of the laboratory

Science and Research Laboratory of Quantum Biology

and Quantum Medicine

V.N. Karazin Kharkiv National University

6 Svobody Sq., Kharkiv, 61022, Ukraine

tel: +38 (057) 707-51-91

e-mail: amkorobov@karazin.ua

ORCID 0000-0001-8237-7159

\section{D.S. Timchenko}

Researcher

Science and Research Laboratory of Quantum Biology and Quantum Medicine

V.N. Karazin Kharkiv National University

6 Svobody Sq., Kharkiv, 61022, Ukraine

tel.: +38 (050) 011-11-30

e-mail: dimatimchenko2020@gmail.com

ORCID 0000-0002-7456-0583

\section{D.O. Kirienko}

\section{Postgraduate}

Surgery Department No. 1

Kharkiv National Medical University

4 Nauky Av., Kharkiv, 61022, Ukraine

tel.: +38 (067) 750-18-73

e-mail:kirden27@gmail.com

ORCID 0000-0001-5290-1159

\author{
E.M. Klimova \\ Dr. Sci. (Biol.), Prof., Head of the laboratory \\ Diagnostic Laboratory with Immunoenzyme and \\ Immunofluorescence Analysis \\ SI "Zaycev V.T. Institute of General and Urgent Surgery \\ of NAMS of Ukraine" \\ 1 Balakirjeva entrance, Kharkiv, 61103, Ukraine \\ tel.: +38 (050) 303-31-72 \\ e-mail: labionhnamnu@gmail.com \\ ORCID 0000-0002-4007-6806
}

\section{E.V. Mushenko}

Cand. Sci. (Med.), Senior Researcher

SI "Zaycev V.T. Institute of General and Urgent Surgery of NAMS of Ukraine"

1 Balakirjeva entrance, Kharkiv, 61103, Ukraine

tel.: +38 (057) 349-41-50

e-mail:dr.mushenko@gmail.com

ORCID 0000-0003-0244-3289

\section{M.V. Pogorielov}

Dr. Sci. (Med.)

Medical Institute

Sumy State University

2 Rymskogo-Korsakova St., Sumy, 40007, Ukraine

tel.: +38 (066) 900-54-48

e-mail:m.pogorielov@gmail.com

ORCID 0000-0001-9372-7791

\section{M.E. Serbin}

Researcher

Science and Research Laboratory of Quantum Biology and Quantum Medicine

V.N. Karazin Kharkiv National University

6 Svobody Sq., Kharkiv, 61022, Ukraine

tel.: +38 (095) 202-53-73

e-mail:makserbin@gmail.com

ORCID 0000-0002-0519-3361

The aim of the study was to improve results of wound healing in patients with ischemic and neuroischemic forms of diabetic foot syndrome by using a combination of phototherapy, platelet-derived growth factor and modern cover materials

The results of surgical treatment of 48 patients with ischemic and neuroischemic diabetic foot syndrome, which were divided into main group (24 patients) and comparison group (24 patients). All these patients who underwent treatment in the Department of acute vascular diseases in the Clinic of the SI "Institute of General and Urgent Surgery named after V.T. Zaitsev of the National Academy of Sciences of Ukraine" suffered from 
diabetes mellitus type II and had IV degree of foot ischemia according to Fontaine. The diagnostic was performed for all patients according to a standard algorithm. Analysis of the results of clinical, laboratory, non-invasive and invasive methods of examination in the preoperative period enabled to determine the degree of disorder in blood flow, the nature of collateral circulation and microcirculation. Patients of both groups underwent femoro-tibial and femoro-popliteal bypass, as well as hybrid reconstructions. The parameters of regional hemodynamics in patients of main group and the comparison group before and after revascularization were comparable.

The patients of main group used the treatment technology developed by us. In cases of development of phlegmons of the foot after the opening of the abscess, vacuum therapy was performed for 7-14 days until the wound was completely cleaned. In the preoperative preparation complex, phototherapy was performed, according to local situation, wounds were irradiated with different wavelengths (405, 470 or $525 \mathrm{~nm}$ ). After the wounds were cleaned, the wound defect was covered with PCL coating (Nanopharma, Czech Republic) with the application of a fibrin clot and platelet-rich plasma without fibrin, after which further local treatment was accompanied by irradiation of wounds with A. Korobov-V. Korobov photon matrices "Barva-Flex" (the wavelength of the maximum of the emission band of $660 \mathrm{~nm}$ ). In two cases, the closure of bone defects with ILAYAOSTEOGEN ${ }^{\circledR}$ “A.A. PARTNERS” L.L.C. bone implants of medical company "ilaya" was used.

Using these tactics, allow to achieve complete wound healing in $91.7 \%$ of patients and partial healing (more than $50 \%$ ) in $8.3 \%$ of patients in main group. The terms of treatment of these patients did not exceed 2 months, high amputations were not required. In patients of comparison group against the background of traditional local treatment, the wounds healed within 2-4 months; in eight cases, repeated hospitalization was required to perform a plastic closure; in two cases amputation was performed below the knee.

Thus, phototherapy and plastic closure of wounds of the lower extremities after revascularization in ischemic diabetic foot syndrome is indicated in cases where the wounds have no tendency to spontaneous healing; introduction of the developed tactics of treatment of "problem" wounds of the lower extremities allowed to achieve complete healing in $91.7 \%$ of patients, partial (more than 50\%) healing in $8.3 \%$ of patients and avoid high amputations; the use of a complex of treatment including phototherapy, wound closure with a synthetic coating with platelet growth factor, and the closure of bone defects with implants is an extremely effective stimulator of development in the wound of granulation tissue suitable for further autodermoplasty.

Key words: ischemic diabetic foot syndrome, dermoplasty, synthetic coatings, phototherapy, platelet growth factor, bone implants.

\title{
ФОТОТЕРАПІЯ В КОМПЛЕКСІ ЛІКУВАННЯ ПРИ ПЛАСТИЧНОМУ ЗАКРИТТІ РАН У ХВОРИХ 3 ІШЕМІЧНОЮ ТА НЕЙРОІШЕМІЧНОЮ ФОРМАМИ СТОПИ ДІАБЕТИКА
}

\author{
Ю.В. Іванова ${ }^{1}$, О.М. Клімова ${ }^{1}$, В.О. Прасол ${ }^{1}$, С.В. Мушенко ${ }^{1}$, А.М. Коробов ${ }^{3}$, \\ М.В. Погорєлов ${ }^{4}$, Д.С. Тімченко ${ }^{3}$, М.Є. Сербін ${ }^{3}$, Д.О. Кіріенко ${ }^{2}$ \\ ${ }^{1}$ ДУ «Інститут загальної та невідкладної хірургї̈ імені В.Т.Зайцева НАМН Украйни», м. Харків, Україна; \\ ${ }^{2}$ Харківський національний медичний університет, м. Харків, Украӥна; \\ ${ }^{3}$ Харківський національний університет імені В.Н. Каразіна, м. Харків, Украйна; \\ ${ }^{4}$ Сумський державний університет, м. Суми, Украӥна
}

Метою проведеного дослідження було поліпшення результатів лікування ран у хворих з ішемічною та нейроішемічною формами синдрому стопи діабетика шляхом застосування в комплексі лікування фототерапії, тромбоцитарного фактора росту і сучасних покривних матеріалів.

В роботі представлені результати хірургічного лікування 48 пацієнтів з синдромом ішемічної та нейроішемічної діабетичної стопи, які відповідно до завдань дослідження були розділені на основну групу (24 пацієнта) і групу порівняння (24 пацієнта). Всі ці пацієнти, які проходили лікування у відділенні гострих захворювань судин клініки дУ «Інститут загальної та невідкладної хірургії імені В.T. Зайцева НАMН України», страждали на цукровий діабет ЦД II типу і мали IV ступінь ішемії стопи по Fontaine. Діагностику проводили всім хворим за стандартним алгоритмом. Аналіз результатів клінічних, лабораторних, неінвазивних і інвазивних методів обстеження в передопераційному періоді дозволяв визначити ступінь порушення магістрального кровотоку, характер колатеральногокровообігу і мікроциркуляції. Пацієнтам обох груп виконувалися стегново-гомілкове і стегново-підколінне шунтування, а також гібридні реконструкції. Показники регіонарної гемодинаміки у пацієнтів основної групи і групи порівняння до і після реваскуляризації можна було порівняти.

У пацієнтів основної групи застосовувалася розроблена нами технологія лікування. У випадках розвитку флегмон стопи після розтину гнійника проводилася вакуумна терапія ран протягом 7-14 діб до повного очищення рани. У комплексі передопераційної підготовки проводили фототерапію - в залежності від локальної ситуації обробляли рани випромінюванням з різними довжинами хвиль $(405,470$ або 525 нм). Після очищення ран від некрозів рановий дефект закривали покриттям PCL (Nanopharma, Чехія) 
с аплікацією фибринового згустку і плазми, збагаченої тромбоцитарним фактором росту без фібрину, після чого подальше місцеве лікування супроводжувалося опроміненням ран фотонними матрицями Коробова А.-Коробова В. «Барва-Флекс »(довжина хвилі максимуму смуги випромінювання 660 нм). У двох випадках використовувалося закриття дефектів кісток кістковими імплантатами ILAYAOSTEOGEN $®$ «A.A. PARTNERS» L.L.C., medical company «ilaya».

Використання розробленої тактики дозволило досягти повного загоєння ран у 91,7\% хворих і часткового загоєння (більше $50 \%$ ) у 8,3\% хворих основної групи. Терміни лікування цих пацієнтів не перевищували 2 місяців, виконання високих ампутацій не було потрібно. У хворих групи порівняння на тлі застосування традиційного місцевого лікування рани гоїлися протягом 2-4 місяців; у восьми спостереженнях була потрібна повторна госпіталізація для виконання пластичного закриття; в двох випадках були виконані ампутації на рівні гомілки.

Таким чином, фототерапія і пластичне закриття ран нижніх кінцівок після операції реваскуляризації при синдромі ішемічної діабетичної стопи показано у випадках, коли рани не мають тенденції до спонтанного загоєнню; впровадження розробленої тактики лікування «проблемних» ран нижніх кінцівок дозволило досягти повного загоєння у 91,7\% хворих, часткового (більше 50 \%) загоєння - у 8,3\% хворих і уникнути виконання високих ампутацій; застосування комплексу лікування, що включає фототерапію, закриття ран синтетичним покриттям з тромбоцитарним фктором росту, а також закриття кісткових дефектів імплантатами є надзвичайно ефективним стимулятором розвитку в рані грануляційної тканини, придатної для подальшої аутодермопластики.

Ключові слова: синдром ішемічної діабетичної стопи, дермопластика, синтетичні покриття, фототерапія, тромбоцитарний фактор росту, кісткові імплантати.

\title{
ФОТОТЕРАПИЯ В КОМПЛЕКСЕ ЛЕЧЕНИЯ \\ ПРИ ПЛАСТИЧЕСКОМ ЗАКРЫТИИ РАН У БОЛЬНЫХ С ИШЕМИЧЕСКОЙ И НЕЙРОИШЕМИЧЕСКОЙ ФОРМАМИ СТОПЫ ДИАБЕТИКА
}

\author{
Ю.В. Иванова ${ }^{1}$, Е.М. Климова ${ }^{1}$, В.А. Прасол ${ }^{1}$, Е.В. Мушенко ${ }^{1}$, А.М. Коробов ${ }^{3}$, \\ М.В. Погорелов ${ }^{4}$, Д.С. Тимченко ${ }^{3}$, М.Е. Сербин ${ }^{3}$, Д.А. Кириенко ${ }^{2}$ \\ ${ }^{1}$ ГУ «Институт общей и неотложной хирургии имени В.Т.Зайцева НАМН Украинъ», г. Харьков, Украина; \\ ${ }^{2}$ Харьковский национальный медицинский университет, г. Харьков, Украина; \\ ${ }^{3}$ Харьковский национальный университет имени В.Н. Каразина, г. Харьков, Украина; \\ ${ }^{4}$ Сумской государственный университет, г. Сумы, Украина
}

Целью проведенного исследования было улучшение результатов лечения ран у больных с ишемической и нейроишемической формами синдрома стопы диабетика путем применения в комплексе лечения фототерапии, тромбоцитарного фактора роста и современных покровных материалов.

В работе представлены результаты хирургического лечения 48 пациентов с синдромом ишемической и нейроишемической диабетической стопы, которые в соответствии с задачами исследования были разделены на основную группу (24 пациента) и группу сравнения (24 пациента). Все эти пациенты, проходившие лечение в отделении острых заболеваний сосудов клиники ГУ «Институт общей и неотложной хирургии имени В.Т. Зайцева НАМН Украины», страдали сахарным диабетом СД II типа и имели IV степень ишемии стопы по Fontaine. Диагностику проводили всем больным по стандартному алгоритму. Анализ результатов клинических, лабораторных, неинвазивных и инвазивных методов обследования в предоперационном периоде позволял определить степень нарушения магистрального кровотока, характер коллатерального кровообращения и микроциркуляции. Пациентам обеих групп выполнялись бедренно-берцовое и бедренно-подколенное шунтирование, а также гибридные реконструкции. Показатели регионарной гемодинамики у пациентов основной группы и группы сравнения до и после реваскуляризации были сопоставимы.

У пациентов основной группы применялась разработанная нами технология лечения. В случаях развития флегмон стопы после вскрытия гнойника проводилась вакуумная терапия ран в течение 7-14 суток до полного очищения раны. В комплексе предоперационной подготовки проводили фототерапию - в зависимости от локальной ситуации обрабатывали раны излучением с различными длинами волн (405, 470 или 525 нм). После очищения ран от некрозов раневой дефект закрывали покрытием PCL (Nanopharma, Чехия) с аппликацией фибринового сгустка и плазмы, обогащенной тромбоцитарным фактором роста без фибрина, после чего дальнейшее местное лечение сопровождалось облучением ран фотонными матрицами Коробова А.-Коробова В. «Барва-Флекс» (длина волны максимума полосы излучения 660 нм). В двух случаях использовалось закрытие дефектов костей костными имплантатами ILAYAOSTEOGEN ${ }^{\circledR}$ «A.A. PARTNERS» L.L.C., medical company «ilaya».

Использование разработанной тактики позволило добиться полного заживления ран у 91,7\% больных и частичного заживления (более 50\%) у 8,3\% больных основной группы. Сроки лечения этих пациентов не превышали 2 месяцев, выполнения высоких ампутаций не потребовалось. У больных 
группы сравнения на фоне применения традиционного местного лечения раны заживали в течение 2-4 месяцев; в восьми наблюдениях потребовалась повторная госпитализация для выполнения пластического закрытия; в двух случаях были выполнены ампутации на уровне голени.

Таким образом, фототерапия и пластическое закрытие ран нижних конечностей после операции реваскуляризации при синдроме ишемической диабетической стопы показано в случаях, когда раны не имеют тенденции к спонтанному заживлению; внедрение разработанной тактики лечения «проблемных» ран нижних конечностей позволило достичь полного заживления у 91,7\% больных, частичного (более 50\%) заживления - у 8,3\% больных и избежать выполнения высоких ампутаций; применение комплекса лечения, включающего фототерапию, закрытие ран синтетическим покрытием с тромбоцитарным фктором роста, а также закрытие костных дефектов имплантатами является чрезвычайно эффективным стимулятором развития в ране грануляционной ткани, пригодной для дальнейшей аутодермопластики.

Ключевые слова: синдром ишемической диабетической стопы, дермопластика, синтетические покрытия, фототерапия, тромбоцитарный фактор роста, костные имплантаты.

\section{Introduction}

Treatment of wounds in patients with ischemic diabetic foot syndrome presents certain difficulties in connection with the feature of the course of the wound process. [1] Monckeberg's sclerosis and arterial calcification are intrinsic for patients with diabetes. These pathological changes are most often determined in the arteries of the shins and feet. In contrast to patients with atherosclerosis with proximal lesions of the arterial bed with a pronounced clinic of shin and foot ischemia and intermittent claudication, patients with diabetes mellitus typically have an occlusive-stenotic lesion of the distal arteries, which often excludes the development of classical intermittent claudication in association with the absence of ischemia of the lower leg muscles, and the combination with the phenomena of diabetic polyneuropathy neutralizes the pain syndrome. All this leads to the fact that manifestation of the disease is most often the development of necrosis of the foot and gangrene of the toes. [1,2]

The presence of polyneuropathy is also of great importance in the pathogenesis of the wound process, in particular, disorder of wound healing processes caused by pathological regeneration. Healing of an ischemic ulcer or a wound of the foot after a debridement is the final goal of surgical treatment, provided the restoration of the blood supply of the foot by a revascularization surgery. [3] However, self-healing of wounds and ulcers is not always possible due to the vastness of the soft tissue defect, sometimes with bone damage, presence of infection, disorder of regeneration against diabetic polyneuropathy, localization of the wound in the "problem area" that is chronically traumatized due to walking, etc. [4]

The aim of the study was to improve the results of wound healing in patients with ischemic and neuroischemic forms of diabetic foot syndrome by using phototherapy (FT), platelet-derived growth factor (TGF), also modern cover materials and bone implants in the complex.

\section{Materials and methods}

The results of treatment of 48 patients with ischemic and neuroischemic forms of diabetic foot syndrome were analyzed, which were divided into two groups, according to the purpose of the study. The main group consisted of 24 patients with ischemic necrosis of toes or feet, who were treated in the Department of Acute Vascular Diseases in the Clinic of the State Institution "Zaycev V.T. Institute of General and Urgent Surgery of NAMS of Ukraine" (SI IGUS) in 2016-2018. The mean age of patients was $67 \pm 3.6$ years, the duration of diabetes was $11 \pm 1.4$ years. All patients had type II diabetes and had the IV degree of foot ischemia according to Fontaine.

The comparison group included 24 patients with ischemic necrosis of the toes or foot and wounds after debridement, which were treated in same department of the SI IGUS in 2013-2015. The average age of patients was $64 \pm 4.2$ years, the duration of the disease of type II diabetes melitus was $10 \pm 1.6$ years; all patients had the IV degree of foot ischemia by Fontaine.

The analysis of the results of clinical, laboratory, non-invasive and invasive methods of examination of patients in the preoperative period enabled to determine the extent of the disorder of of the blood flow, the nature of the collateral circulation and microcirculation. Diagnostics was done to all the patients according to a standard algorithm:

1) Histori of disease, clinical and laboratory examination: duration of the disease, intermittent claudication, pain at rest, presence and nature of necrosis, pulse on the main arteries; analysis of laboratory methods of research and anamnesis of comorbidity .

2) Non-invasive examination included determination of the index of regional systolic pressure on the arteries of the foot using a portable ultrasound device "Super Dopplex" (China); ultrasound dopplerography using the Hitachi EUB 7500 device (Japan) with linear sensor L 5-10 MHz; the determination of the oxygen tension (TcPO2) in the foot tissues percutaneously with the aid of the TCM 400 apparatus "Radiometer Copenhagen" (Denmark).

3) As an invasive study, angiography was performed using "Philips Integris Allura" device (Holland).

In the postoperative period, a control determination of the index of the regional systolic pressure on the arteries of the foot, ultrasound examination of the arterial reconstruction zone and the determination of TcPO2 in the foot tissues were done.

From 24 patients in the main group, 4 patients underwent femoro-tibial bypass, in 15 cases - fem- 
oral-popliteal reconstruction; 5 patients underwent a hybrid reconstructive surgery (femoral-popliteal reconstruction in combination with balloon angioplasty of tibial arteries). 15 patients had wounds after debridment and small amputations on the foot, which could not be closed with auto-dermoplasty; 2 patients had foot phlegmon, and 3 has infected wounds; in 4 patients, wounds were localized on the plantar surface of the foot; in 2 cases there were marginal lesions of the foot bones.

From 24 patients in the comparison group, $18 \mathrm{had}$ a femoral-popliteal reconstruction, 2 had femoral-femoro-tibial bypass, and 4 had a hybrid reconstruction. 13 patients had wounds after necroctomy and small amputations on the foot, 3 patients had foot phlegmon, and 3 had infected wounds; in 5 patients, wounds were localized on the plantar surface of the foot.

Treatment for patients of both groups was prescribed according to the following scheme: compensation of diabetes mellitus (transfer to fractional insulin therapy); metabolic therapy, antibacterial, anticoagulant and vasotrophic therapy; physical methods of treatment; therapy aimed at treating osteoporosis (calcium drugs).

The patients of the comparison group underwent traditional treatment of wounds of the foot after debridement using daily dressings with antiseptics, ointments, sorbents, etc.

In order to improve the results of treatment of wounds and ulcers of the lower extremity, the following treatment methods and their combinations were used in the patients of the treatment group: phototherapy; stage closure of tissue defects with a synthetic coating of polycaprolactone (PCL, Nanopharma, Czech Republic) with application of a fibrin clot and plasma enriched with TGF without fibrin; vacuum therapy with Acti VAC apparatus manufactured by KCI (USA); autodermoplasty according to Thiersch; free autodermoplasty with split-thickness skin graft.

For phototherapy in the complex of local treatment of wounds, A. Korobov-V. Korobov flexible photonic (LED) matrices "Barva Flex" were used with different wavelengths of the maximum emission band $-405 \mathrm{~nm}$, $470 \mathrm{~nm}, 525 \mathrm{~nm}$ and $660 \mathrm{~nm}$, which corresponded to violet, blue, green and red spectral ranges, with various therapeutic effects. [5] Indications for the use of FT were long-term ischemia with necrobiosis of wound tissues; the presence of an infected or purulent wound.

The use of vacuum therapy for treatment of wounds of the foot ensured the purification of the wound and the stimulation of the growth of the granulation tissue in the wound for further closure it with a synthetic coating or the performance of autodermoplasty.

Closure of wounds with a synthetic coating with the application of a fibrin clot and plasma enriched with TGF without fibrin prevented the development of secondary infection, stimulated the growth of connective (granulation) tissue in the wound for subsequent autodermoplasty or healing it under the coating by wound contraction. Indications for use of this method for treating wounds in ischemic diabetic foot syndrome were the presence of a defect in the foot tissues, which cannot be closed by autodermoplasty (the bottom of the wound is represented by bone or adipose tissue, tendons) or the presence of a defect in the foot tissues requiring for closing with own tissues of bone resection, which significantly worsens the foot supportability.

Autodermoplasty was used for final closure of the wound of the foot after the preliminary stage of treatment. Indications for autodermoplasty were the presence of a healthy granulation tissue on the bottom of the wound and absence of a tendency to spontaneous healing.

The purpose of closure of the bone defects with the ILAYAOSTEOGEN ${ }^{\circledR}$ (“A.A. PARTNERS” L.L.C., medical company "ilaya") implants was to prevent the development of osteomyelitis and stimulation of osteogenesis.

We developed and applied the following scheme of treatment of the ischemic and neuroischemic diabetic foot.

At the stage of preparation for the revascularization, in the presence of pronounced edema, $3-5$ sessions of blue light FT were performed (wavelength of 440-470 nm, duration of the session of 5-10 minutes). In the absence of perifocal edema, light treatment of wounds was done by conducting 3-5 irradiation sessions with green light (wavelength of $520-550 \mathrm{~nm}$, duration of the session of 3-5 minutes). The radiation power density at FT was in the range of $0.1-1.0 \mathrm{~W} / \mathrm{cm}^{2}$, and the time of exposure to the wound varied depending on its area. The density of the radiation supplied to the wound was on average $30-40 \mathrm{~J} / \mathrm{cm}^{2}$.

If necessary, phlegmons were opened, surgical treatment of wounds with excision of necrosis and elimination of purulent fouling and vacuum therapy were performed.

After stabilization of hemodynamic parameters and formation of a clear demarcation zone, debridement or amputation of necrotic toes with resection of heads of metatarsal bone was performed. The open wound surfaces were covered with a synthetic coating of polycaprolactone (while modeling the contour congruently to the edges of the wound and fixing with the Prolene 5 suture material, if necessary) with the application of a fibrin clot and plasma enriched with TGF without fibrin.

The plasma was obtained as follows: $20 \mathrm{ml}$ of blood were taken without a preservative from the cubital vein. The blood was ultracentrifuged to obtain a fraction enriched with TGF. A day later, during the second dressing, the remains of the fibrin clot were removed, and the wound coating was irrigated with plasma enriched with an auto-platelet-derived growth factor. In two cases, marginal bone resections were performed with the replacement of defects with 
ILAYAOSTEOGEN ${ }^{\circledR}$ (“A.A. PARTNERS” L.L.C., medical company "ilaya”) bone implants of appropriate size.

After that, the daily irradiation of wounds with red light was performed (wavelength of 630-660 nm, duration of FT sessions of 10-15 minutes, the frequency of sessions depended on the area of wounds), until conditions appeared for performing plastic closure of defects or healing by wound contraction.

Subsequently, daily dressings were performed with the treatment of the coating with antiseptics (Dioxidin, Octenisept, etc.). If there were no signs of suppuration under the coating, the dressings were performed for 14-32 days with a gradual cutting of the edges of the synthetic coating as wound contraction and marginal epithelialization occurred. In the absence of a tendency to heal wounds after 1 month, the coating was removed and autodermoplasty according to Thiersch or with a split perforated skin graft was planned. With obvious signs of suppuration under the coating (2 cases), it was removed, the wound was sanitized for 3-5 days, and then the wound closure procedure with a synthetic coating was repeated or a system for vacuum treatment of wounds was installed.

In cases of manifestation of infection in the wounds of the feet after revascularization and phlegmon formation, abscesses were opened with the installation of the vacuum system for 7-14 days before the wound was cleaned, after which the developed treatment complex (5 patients) was applied.

When the wound was localized on the plantar surface of the foot (in 4 cases), which complicated the autodermoplasty, the developed method of closure with a synthetic coating was used (the duration of treatment was 1-2 months).

In all cases, the patients signed an agreement for participation in the study. The entire list of studies and the methods of treatment used was approved by the Ethical Commission of the State Institution "Zaycev V.T. Institute of General and Urgent Surgery of NAMS of Ukraine".

\section{Results and discussion}

The parameters of regional hemodynamics in patients of main group before and after various revascularization operations are given in Table 1.
When examining patients of the comparison group after revascularization operations, comparable indicators of regional hemodynamics were determined.

Among the patients of the treatment group, who had the closure of wounds of the foot with the use of polymer coating, in 13 patients spontaneous epithelization of wounds under the coating in the period up to 35 days occurred. In 9 patients, after the removal of the coating and the surgical treatment of the wound before contact bleeding, autodermoplasty was performed: grafting with split perforated flap for 6 patients and that according to Thiersch for 3 patients. One patient refused autodermoplasty, the wound was gradually healed by secondary tension for 4 months with epithelization by $70 \%$. In all patients after grafting with a split perforated skin graft, a full epithelialization of the wound was determined after 1 month. In one case, partial (more than 50\%) epithelialization of the wound was achieved after grafting according to Thiersch, which required repeated skin grafting.

In 5 patients of the treatment group, who were treated with the use of a vacuum system for phlegmon or infected wounds, it was possible to achieve cleansing of the wounds after 7-14 days of treatment. Subsequently, the developed treatment tactics was applied. The healing time for the wounds was 4-6 weeks.

Of the 24 patients in the comparison group, who received traditional treatment, the wounds were completely healed by secondary tension for 2-4 months and by wound contraction in 8 cases. Reduction of wound area to $50 \%$ was observed in 6 patients. In 10 patients, there was no tendency for wound healing and there was a progression of the necrotic process, which in 8 cases required re-hospitalization and plastic closure of the wound, and in 2 cases it caused amputation below the knee.

Clinical case. Patient K., 68 years old, was admitted to the hospital with CLI critical limb ischemia of the right lower extremity in the background of type II diabetes mellitus. He was treated for 2 months in the central district hospital at his place of residence, where an amputation of the first toe with a metatarsal bone was performed for him. According to ultrasound examination and angiography, an extended occlusion of the popliteal and anterior tibial artery was noted. There is extensive necrosis on the foot (in the region of the

\section{Indicators of regional hemodynamics in patients of the treatment group}

Table 1 before and after revascularization

\begin{tabular}{|c|c|c|c|c|c|c|}
\hline \multirow{2}{*}{$\begin{array}{c}\text { Type of surgery } \\
\text { Index }\end{array}$} & \multicolumn{2}{|c|}{$\begin{array}{c}\text { Femoro-tibial } \\
\text { bypass }-4(16.7 \%) \text { cases }\end{array}$} & \multicolumn{2}{|c|}{$\begin{array}{c}\text { Femoral-popliteal } \\
\text { bypass }-15(62.5 \%) \text { cases }\end{array}$} & \multicolumn{2}{|c|}{$\begin{array}{c}\text { Hybrid reconstructive } \\
\text { surgery }-5(20.8 \%) \text { cases }\end{array}$} \\
\hline & $\begin{array}{l}\text { Before the } \\
\text { surgery }\end{array}$ & $\begin{array}{l}\text { After the } \\
\text { surgery }\end{array}$ & $\begin{array}{l}\text { Before the } \\
\text { surgery }\end{array}$ & $\begin{array}{l}\text { After the } \\
\text { surgery }\end{array}$ & $\begin{array}{l}\text { Before the } \\
\text { surgery }\end{array}$ & $\begin{array}{l}\text { After the } \\
\text { surgery }\end{array}$ \\
\hline $\begin{array}{c}\text { Index of regional } \\
\text { systolic pressure } \\
\text { on the arteries of } \\
\text { the foot }\end{array}$ & $0.34 \pm 0.04$ & $0.82 \pm 0.06$ & $0.27 \pm 0.03$ & $0.67 \pm 0.08$ & $0.19 \pm 0.06$ & $0.91 \pm 0.05$ \\
\hline $\begin{array}{l}\text { TcPO2 }(\mathrm{mm} \mathrm{Hg}) \\
\text { at the foot }\end{array}$ & $16.8 \pm 4.6$ & $48.6 \pm 7.5$ & $9.4 \pm 3.5$ & $39.6 \pm 6.7$ & $5.3 \pm 2.5$ & $32.9 \pm 5.7$ \\
\hline
\end{tabular}


distant 1 st toe and the metatarsal bone, in the bottom of one of the wounds, the bonesaw-line of the metatarsal bone with signs of osteomyelitis is visualized (Fig. 1).

After preoperative preparation, which included, in addition to traditional measures, phototherapy with green light (wavelength of 520-550 nm, duration of the session of 3-5 minutes, the frequency of 5 sessions, see Fig. 2), in a planned manner, the femoro-tibial autovenous bypass was performed.

After the revascularization operation, 3 sessions of FT with green light were performed in the local treatment complex, followed by debridement (Fig. 3).

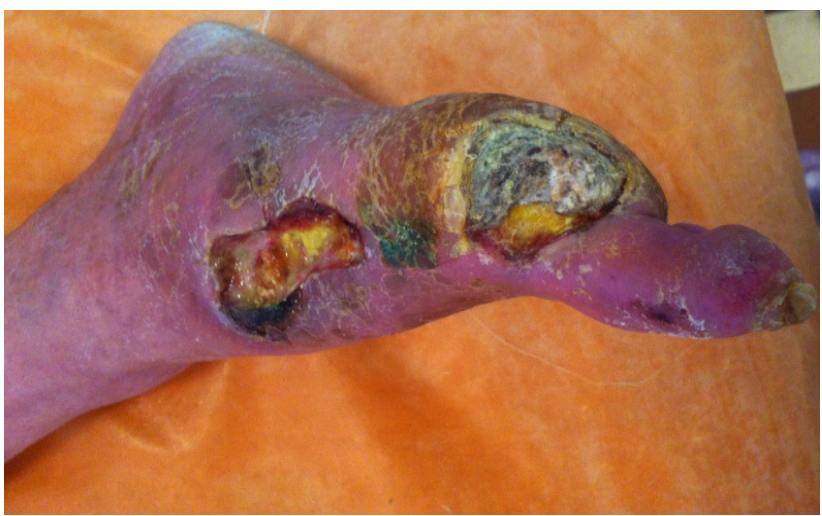

Fig. 1. Patient K., 68 years old. Type of foot at admission

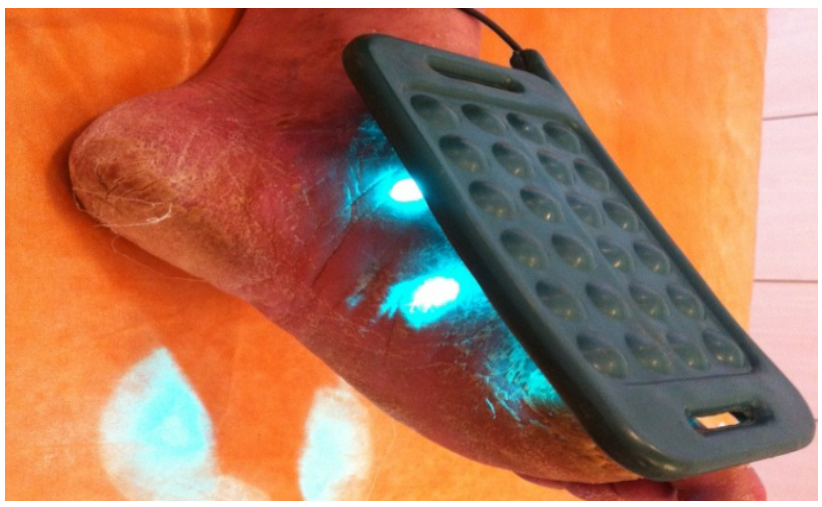

Fig. 2. Phototherapy at the stage of preoperative preparation

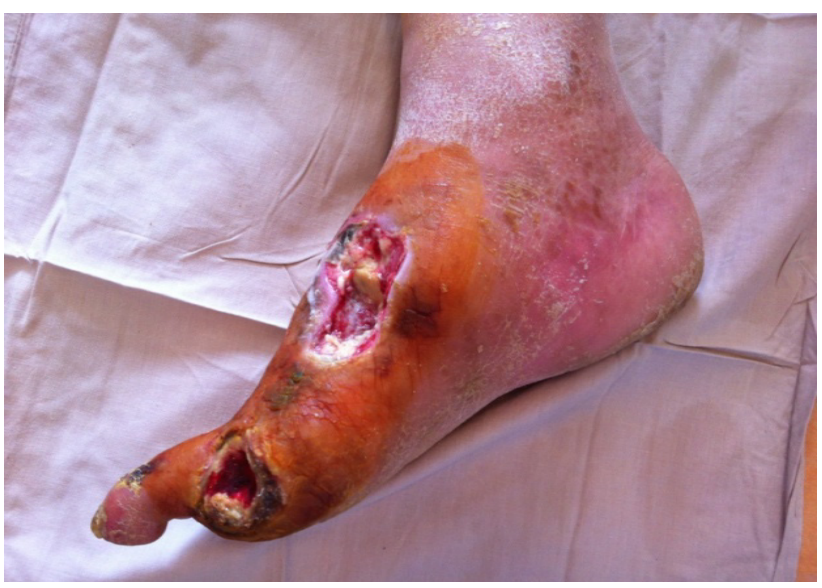

Fig. 3. Type of wound after debridement ( 3 days after surgery)
Later, during dressings, the wound was treated with solutions of antiseptics and daily irradiated with red light (wavelength of 630-660 nm, duration of sessions of 10 minutes).

On 10 day after the revascularization in the dressing room, an edge resection of the changed part of the metatarsal bone was performed, the defect was closed with the ILAYAOSTEOGEN ${ }^{\circledR}$ (“A.A. PARTNERS” L.L.C., medical company "ilaya”) bone implant (Fig. 4). The implementation of phototherapy continued.

On 12 day of treatment in the dressing room, the wound was closed with a synthetic coating of polycapro-

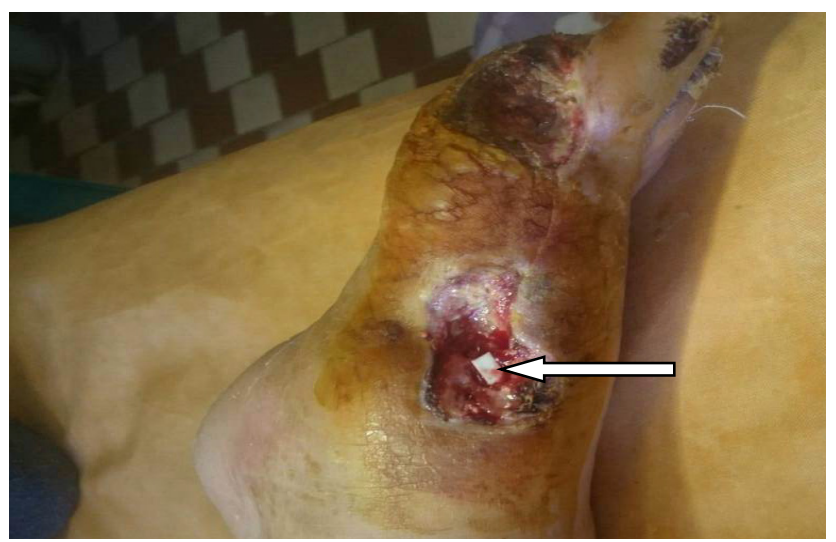

Fig. 4. The wound after surgical treatment and installation of the ILAYAOSTEOGEN ${ }^{\circledR}$ bone implant

(shown by an arrow)

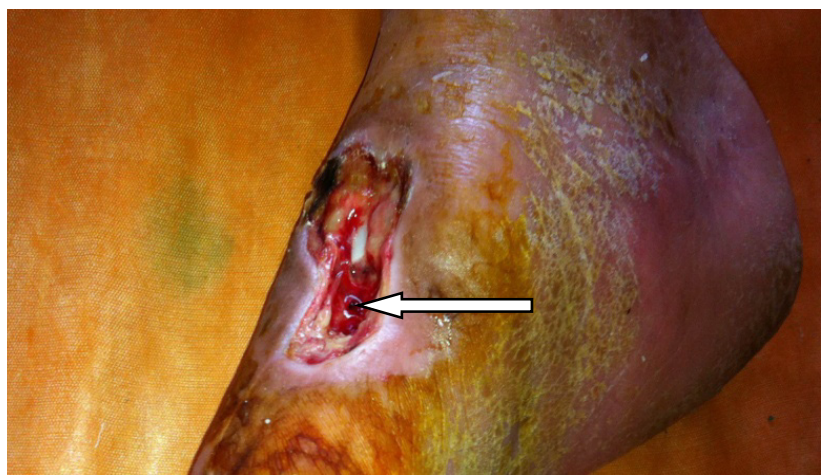

Fig. 5. The wound with a fibrin clot (shown by an arrow)

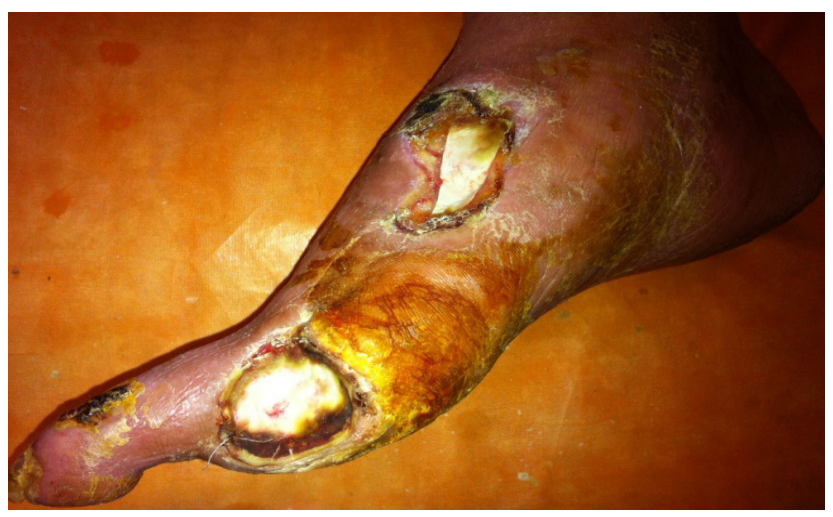

Fig. 6. The wounds are covered with a synthetic coating of polycaprolactone (the appearance of wounds on the 3rd day after the manipulation) 
lactone (with contour modeling congruently to the wound edges), and the application of a fibrin clot with plasma enriched with TGF without fibrin according to the developed technique was performed (Fig. 5, Fig. 6).

The patient was discharged on the day 15 after the operation. Later, local treatment was performed in the regime of a day hospital. The wounds healed on the day 31 after the surgery.

\section{Conclusions}

1. Phototherapy and plastic closure of wounds of the lower extremities after a revascularization operation in ischemic diabetic foot syndrome is indicated in cases when the wounds have no tendency to spontaneous healing.

2. Implementation of the developed tactics of treatment of "problem" wounds of the lower extremities allowed to achieve their complete healing in $91.7 \%$ of patients, partial healing (more than 50\%) in 8.3\% of patients, and avoid high amputations.

3. In our opinion, the use of a complex of treatment including phototherapy, wound closure with a synthetic coating with TGF, and the closure of bone defects with implants ILAYAOSTEOGEN ${ }^{\circledR}$ is an extremely effective stimulator of development in the wound of granulation tissue suitable for subsequent autodermoplasty.
4. We consider the researching of cellular regeneration mechanisms and histological study of the stages of development of connective tissue under the influence of phototherapy, allodermoplasty and TGF, as well as the feasibility of using a combination of synthetic coatings and TGF with vacuum therapy to be promising directions for the development of this method of treatment.

\section{References}

1. Norgren L, Hiatt WR, Dormandy JA, Nehler MR, Harris KA, Fowkes FG; TASC II Working Group. Inter-society consensus for the management of peripheral arterial disease (TASC II). J Vasc Surg. 2007 Jan;45:5.

2. Eskelinen E, Luther M, Eskelinen A, Lepantalo M. Infrapopliteal bypass reduces amputation incidence in elderly patients: a population-based study. Eur J Vasc Endovasc Surg. 2003;26:65.

3. Eltzschig HK, Collard CD. Vascular ischaemia and reperfusion injury. Br Med Bull. 2004;70:71-86.

4. Gibbons GW. Lower extremity bypass in patients with diabetic foot ulcers. Surg Clin North Am. 2003;83:659.

5. Korobov AM, Korobov VA, Lesnaya TA. Fototerapevticheskie apparatyi Korobova serii "Barva"[Phototherapy Korobov devices of the "Barva" series]. 2nd ed. Harkov: Kontrast Publ.; 2008. 176 p. (in Russian) 